\title{
Vanadium Contribution to the Surface Modification of Titanium Silicalite for Conversion of Benzene to Phenol
}

\author{
Mulyatun $^{1}$ and Didik Prasetyoko ${ }^{2}$
}

\begin{abstract}
Vanadium oxide supported on the surface of titanium silicalite was investigated in benzene hydroxylation to determine its activity as heterogeneous catalyst. Effect of vanadium loading on structure and activity of titanium silicalite was investigated. On the basis of $\mathrm{X}$-ray diffraction and infrared spectroscopy techniques, it was found that the titanium structure was remained on the modified catalyst. The catalytic activity of the modified catalyst was observed to be higher than that of parent catalyst.
\end{abstract}

Keywords—titanium silicalite, vanadium oxide, hydroxylation, benzene

Abstrak-Aktivitas vanadium oksida yang berada pada permukaan titanium silikalit sebagai katalis heterogen telah diteliti pada hidroksilasi benzena. Pengaruh loading vanadium terhadap struktur dan aktivitas titanium silikalit telah dipelajari. Berdasarkan teknik difraksi sinar-X dan spektroskopi inframerah, ditemukan bahwa titanium pada katalis yang telah dimodifikasi tidak mengalami perubahan struktur. Aktivitas katalitik dari katalis yang telah dimodifikasi diamati lebih tinggi dibandingkan dengan katalis induk.

Kata Kunci-titanium silikalit, vanadium oksida, hidroksilasi, benzena

\section{INTRODUCTION}

$\mathrm{P}$ henol is an important intermediate compound for the synthesis of petrochemicals, agrochemicals, and plastics. Nowadays approximately $95 \%$ of phenol production was produced by cumene process consisting of three main reaction steps (alkylation of benzene with propylene to cumene, oxidation of cumene to cumene hydroperoxide and decomposition to phenol and acetone) [1]. The advantage of the cumene process is that it takes two inexpensive starting materials, benzene and propylene and converts them into two high value useful products, phenol and acetone, using air. Despite its great success, the cumene process has some disadvantages such as the production of an explosive intermediate (cumene hydroperoxide), it has a high environmental impact, and it uses a corrosive catalyst. It is multi-step process, which makes it difficult to achieve high phenol yields in relation to benzene used and which leads to a high capital investment. It requires the uses of aggressive media (dilute sulphuric acid at $60-70^{\circ} \mathrm{C}$ ) and has a high acetone production as a co-product which results in an over supply in the market [2]. This situation encouraged scientists to develop other methods for producing phenol from benzene, preferably via a single-step and free of coproducts reaction, which thus would be economically favorable.

The direct hydroxylation of benzene to phenol is an attractive alternative to phenol production for economically and environmentally reason [3]. One of the alternative routes to produce phenol which has more

Mulyatun is with Department of Chemical Education, Faculty of Education, Institut Agama Islam Negeri Walisongo, Semarang, Indonesia.

Didik Prasetyoko is with Department of Chemistry, FMIPA, Institut Teknologi Sepuluh Nopember, Surabaya, 60111, Indonesia. E-mail: didikp@chem.its.ac.id. advantages is through benzene hydroxylation reaction using $\mathrm{H}_{2} \mathrm{O}_{2}$ as oxidant agent and Titanium Silicalite-1 (TS-1) as catalyst. TS-1 is known to be an excellent catalyst for hydroxylation of benzene with selectivity to phenol reach $97 \%$ [4]. TS-1 catalyst has high catalytic activity and selectivity in oxidation reaction of aromatic compounds with $\mathrm{H}_{2} \mathrm{O}_{2}$ which important for commercial industries [5]. However, the reaction rate of benzene hydroxylation tends to be low [6]. It is because TS-1 has hydrophobic nature [5], and as the result $\mathrm{H}_{2} \mathrm{O}_{2}$ adsorption which has hydrophilic nature towards active sites of TS-1 is also become slower.

Meanwhile, in the hydroxylation reaction, it is well known that the interaction between titanium and oxidizing agents $\left(\mathrm{H}_{2} \mathrm{O}_{2}\right)$ to form titanium-peroxo species as intermediate species from reaction between $\mathrm{H}_{2} \mathrm{O}_{2}$ and TS-1 catalyst [7-9], should occur before the reaction with benzene to produce phenol. The rate of the formation of titanium-peroxo depends on the rate of $\mathrm{H}_{2} \mathrm{O}_{2}$ reach to active site in TS-1. One of the ways to increase benzene hydroxylation reaction rate with TS-1 catalyst is by making TS-1 become more hydrophilic, and the reaction rate of benzene hydroxylation will be much faster, and it's catalytic activity and selectivity higher than TS-1. Hydrophilic improvement of catalyst can be carried out by addition of metal oxide which leads to increasing of acidity properties. The metal oxide in TS-1 catalyst which act as acid site capable to increase catalyst hydrophilicity, so that reactant adsorption in catalyst becomes faster $[10,11]$. In previous research done by Indrayani [12], $\mathrm{MoO}_{3} / \mathrm{TS}-1$ catalysts have showed improvement of hydrophilicity along with the increasing of $\mathrm{MoO}_{3}$ content in $\mathrm{MoO}_{3} / \mathrm{TS}-1$ catalyst. The improvement of hydrophilic character of $\mathrm{MoO}_{3} / \mathrm{TS}-1$ catalyst is also accompanied with the improvement of its catalytic activity. In this research, TS-1 catalyst was 
modified by addition of metal oxide $\mathrm{V}_{2} \mathrm{O}_{5}$ on the surface of TS- 1 catalyst. The existence of $\mathrm{V}_{2} \mathrm{O}_{5}$ on the TS-1 surface was observed to make this catalyst $\left(\mathrm{V}_{2} \mathrm{O}_{5} / \mathrm{TS}-1\right)$ has higher hydrophilic character as compared to TS-1.

\section{METHOD}

\section{A. Samples Preparation}

TS-1 catalyst samples were prepared according to a procedure described earlier by Taramasso et al. [13]. Tetraethyl orthosilicates, TEOS (Merck, 98\%) containing $0.3145 \mathrm{~mol}$ of silicon was placed into a Teflon beaker and vigorously stirred. Tetraethyl orthotitanate, TEOT (Merck, 95\%) containing 0.0032 mol of titanium in isopropyl alcohol was carefully added drop-wise into this TEOS. The beaker was covered with parafilm to avoid hydrolysis by air. The reactants were mixed homogeneously for 30 minute at room temperature. Then the mixture was cooled to about $0^{\circ} \mathrm{C}$. The solution of tetrapropylammonium hydroxide, TPAOH (Merck, 20\% TPAOH in water), which was used as template, was also cooled to $0^{\circ} \mathrm{C}$. After a few minutes, TPAOH containing $0.1287 \mathrm{~mol}$ of TPAOH was added drop-wise slowly into the mixture of TEOS and TEOT. At first, one should wait a few minutes after addition of a few drops of TPAOH solution before more TPAOH solution is added, to avoid precipitation. Stirring and cooling were continued during this process. When the addition of TPAOH was completed, the mixture was heated in the temperature range of $80-90^{\circ} \mathrm{C}$ for about 4 hour in order for the hydrolysis of TEOS and TEOT to take place. Distilled water was added to increase the volume of the mixture to about $127 \mathrm{~mL}$, after which a clear gel was obtained. The gel was transferred into a $150 \mathrm{~mL}$ autoclave and heated at $175^{\circ} \mathrm{C}$ under static condition. The material was recovered after 4 days of hydrothermal crystallization by centrifugation and washing with excess distilled water. A white powder was obtained after drying in air at $100^{\circ} \mathrm{C}$ overnight [13].

The $\mathrm{V}_{2} \mathrm{O}_{5} / \mathrm{TS}-1$ catalysts were prepared by impregnation of TS-1 with an aqueous solution containing sufficient amount of ammonium methavanadate $\left(\mathrm{NH}_{4} \mathrm{VO}_{3}\right)$, to yield materials with loading in the ranges of $0.5-4 \mathrm{wt} \%$ of $\mathrm{V}_{2} \mathrm{O}_{5}$. The suspension was heated at $80^{\circ} \mathrm{C}$ for $3 \mathrm{~h}$ under stirring condition, followed by evaporation of water, draining at $110^{\circ} \mathrm{C}$ for $24 \mathrm{~h}$, and calcination at $500^{\circ} \mathrm{C}$ for $5 \mathrm{~h}$ [14]. The samples were denoted by their weight percentage of $\mathrm{V}_{2} \mathrm{O}_{5}$ on TS-1.

\section{B. Characterizations}

The structure of catalyst TS- 1 and $\mathrm{V}_{2} \mathrm{O}_{5} / \mathrm{TS}-1$ was determined using X-ray powder diffraction (XRD) and infrared spectroscopy technique. X-ray powder diffraction (XRD) patterns were collected using the $\mathrm{Ni}$ filtered $\mathrm{Cu}-\mathrm{K}_{\alpha}$ radiation $(\lambda=1.5406 \AA)$ as the diffracted monochromatic beam at $40 \mathrm{kV}$ and $40 \mathrm{~mA}$. The pattern was scanned in the $2 \theta$ ranges from $5^{\circ}$ to $50^{\circ}$ at a step size $0.010^{\circ}$ and step time $1 \mathrm{~s}$. Infrared spectra of the catalyst TS-1 and $\mathrm{V}_{2} \mathrm{O}_{5} / \mathrm{TS}-1$ samples were collected on a Shimadzu Fourier Transform Infrared, with scans $20 \mathrm{~s}$ by $\mathrm{KBr}$ pellet method. The Infrared spectra were recorded in the region of $1400-400 \mathrm{~cm}^{-1}$. The acidity of samples was determined by infrared spectroscopy technique using pyridine as probe molecule. The water of the sample (10$12 \mathrm{mg}$ ) was locked in the cell equipped and evacuated at $400^{\circ} \mathrm{C}$ under nitrogen flow for $4 \mathrm{~h}$, continued by adsorption of pyridine at room temperature. After evacuation at $150^{\circ} \mathrm{C}$ for $3 \mathrm{~h}$, infrared spectra of the sample were recorded at room temperature in the region of $1400-1700 \mathrm{~cm}^{-1}$ using Shimadzu Fourier Transform Infrared (FTIR). The catalysts hydrophilicity is analyzed by catalyst sample powder dispersion method at water phase and organic phase mixture (water and xylene). A mixture of xylene and water, which do not mix each other, is employed to test the hydrophobic characteristics of the samples. xylene and water of the same volume are added into a test tube to form a stable phase interface. TS- 1 and $\mathrm{V}_{2} \mathrm{O}_{5} / \mathrm{TS}-1$ catalyst samples are, respectively, dispersed in the xylene-water system and stirred. After the mixture has stabilized, the hydrophobic characteristics can be qualitatively evaluated by inspecting the state of the floating/sinking of samples at the interface [15].

\section{Catalytic Activity}

The catalyst performance was tested in the hydroxylation of benzene using aqueous $\mathrm{H}_{2} \mathrm{O}_{2}(30 \%)$ as oxidant. The reaction mixture containing benzene $(1 \mathrm{~g})$, $\mathrm{H}_{2} \mathrm{O}_{2}(1.32 \mathrm{~mL})$, and acetoneitrile $(5 \mathrm{~g})$ as solvent was placed in a round bottom flask equipped with a condenser. The catalyst ( $0.15 \mathrm{~g}$ TS- 1 based) was then added to the mixture. The reaction was carried out in an oil bath under stirring at $70^{\circ} \mathrm{C}$. The products of the reaction were analyzed by a Agilent gas chromatograph using an HP 5 non polar column with FID detector.

\section{RESULTS AND DISCUSSION}

\section{A. Structural Characterization of $\mathrm{V}_{2} \mathrm{O}_{5} / \mathrm{TS}-1$ Materials}

TS- 1 and $\mathrm{V}_{2} \mathrm{O}_{5} / \mathrm{TS}-1$ catalysts were characterized by $\mathrm{X}$-ray diffraction technique. The XRD patterns of the $\mathrm{V}_{2} \mathrm{O}_{5}$, TS-1 and $\mathrm{V}_{2} \mathrm{O}_{5} / \mathrm{TS}-1$ samples with various vanadium loading are shown in Figure 1. Characteristic diffraction lines of TS- 1 is observed at $2 \theta=7.94$; 8 ; $23.08 ; 23.62 ; 23.88 ; 23.92^{\circ}$. The peak at $2 \theta$ around $24^{\circ}$ is observed for the orthorombic symmetry, which is symmetry of TS-1. This Phenomenon indicates that titanium atom is already existed in the framework structure of TS-1 [16]. No diffraction line assigned for crystalline phase of the vanadium $(\mathrm{V})$ oxide is present in the XRD pattern of $\mathrm{V}_{2} \mathrm{O}_{5} / \mathrm{TS}-1$ catalysts; and generally, the MFI structure of TS-1 still retained after dispersion of $\mathrm{V}_{2} \mathrm{O}_{5}$ to TS-1. This finding indicated that the MFI structure of TS-1 is not collapsed after impregnation of $\mathrm{V}_{2} \mathrm{O}_{5}$. The peak at $2 \theta, 20.2$ corresponding to $\mathrm{V}_{2} \mathrm{O}_{5}$ is not observed even for higher loadings which suggests that an amorphous or a highly dispersed state of $\mathrm{V}_{2} \mathrm{O}_{5}$ on the surface of the support or the crystallites formed are less than $4 \mathrm{~nm}$ in size that is beyond the detection capability of the XRD technique [14, 17]. Thus, the absence of any $\mathrm{V}_{2} \mathrm{O}_{5}$ or orthovanadate peaks at lower loadings, is a clear indication that vanadia exists in a highly dispersed state on the support surface. 
However, the peak intensities of the $\mathrm{V}_{2} \mathrm{O}_{5} / \mathrm{TS}-1$ samples decrease with the increase of $\mathrm{V}_{2} \mathrm{O}_{5}$ loading, due to the increase concentration of the $\mathrm{V}_{2} \mathrm{O}_{5}$ on the surface of the TS-1. It is suggested that $\mathrm{V}_{2} \mathrm{O}_{5}$ could be located on the surface of TS- 1 or covering the surface of TS-1. The crystallinity of $\mathrm{V}_{2} \mathrm{O}_{5} / \mathrm{TS}-1$ catalysts (based on the highest diffraction line of TS-1) are summarized in Table 1.

The infrared spectra of the samples are shown in Figure 2. Vanadium (V) oxide crystal exhibits four strong absorption bands at around 1022, 835, 627 and $480 \mathrm{~cm}^{-1}$. The band at $1022 \mathrm{~cm}^{-1}$ could be assigned to (V $=\mathrm{O})^{3+}$ double bond stretching mode. The bands at 835 and $480 \mathrm{~cm}^{-1}$ are due to the asymmetric stretching mode and the rotation mode of $\mathrm{V}-\mathrm{O}-\mathrm{V}$ vibrations, respectively [18].

Catalyst samples of TS- 1 and $\mathrm{V}_{2} \mathrm{O}_{5} / \mathrm{TS}-1$ shows absorption band at around 1100, 800, and $450 \mathrm{~cm}^{-1}$, which is vibration mode of $\mathrm{SiO}_{4}$ or $\mathrm{AlO}_{4}$ tetrahedral. Absorption band at around $1100 \mathrm{~cm}^{-1}$ is asymmetrical vibration mode of $\mathrm{Si}-\mathrm{O}-\mathrm{Si}$, and absorption band at around $800 \mathrm{~cm}^{-1}$ is its symmetrical vibration mode. Absorption band around 1230 and $547 \mathrm{~cm}^{-1}$ is characteristic for tetrahedral structure in framework zeolite MFI [19]. Absorption band at around $970 \mathrm{~cm}^{-1}$ is characteristic of TS-1 which is vibration mode of stretching $\mathrm{Si}-\mathrm{O}$ from unit $\left[\mathrm{SiO}_{4}\right]$ which tied at atom $\mathrm{Ti}^{4+}$ with tetrahedral coordination in TS-1 framework. Absorption band at this wavenumber is an evidence that titanium atom has already stayed inside the structure of catalyst framework [20]. No additional band after impregnation of $\mathrm{V}_{2} \mathrm{O}_{5}$ on the TS- 1 can be observed. This finding shows that impregnation of $\mathrm{V}_{2} \mathrm{O}_{5}$ has not affected the MFI structure of TS- 1 significantly.

The acidity of $\mathrm{V}_{2} \mathrm{O}_{5} / \mathrm{TS}-1$ catalyst samples was investigated by infrared spectroscopy using pyridine as the probe molecule. Figure 3 shows the infrared spectra of the samples at various $\mathrm{V}_{2} \mathrm{O}_{5}$ loadings after evacuation at $150^{\circ} \mathrm{C}$ under vacuum for $3 \mathrm{~h}$. TS- 1 catalyst sample shows peaks at around 1490 and $1445 \mathrm{~cm}^{-1}$. The peak at around $1445 \mathrm{~cm}^{-1}$ is assigned to Lewis acid sites, suggesting that TS-1 possesses only Lewis acid. Similar finding has been reported by Drago et al. [19]. Meanwhile, all $\mathrm{V}_{2} \mathrm{O}_{5} / \mathrm{TS}-1$ samples show peaks at around 1546, 1490, and $1445 \mathrm{~cm}^{-1}$. The small peak at around $1546 \mathrm{~cm}^{-1}$ and the strong peak at around $1445 \mathrm{~cm}^{-1}$ indicate that all samples contain both Brønsted and Lewis acid sites. The calculated amount of Lewis and Brønsted acid sites in the TS- 1 and $\mathrm{V}_{2} \mathrm{O}_{5} / \mathrm{TS}-1$ catalyst samples is tabulated in Table 2, calculated according to the equation method introduced by Emeis [21]. The impregnation of $\mathrm{V}_{2} \mathrm{O}_{5}$ in TS-1 results in the existence of interaction between $\mathrm{V}_{2} \mathrm{O}_{5}$ and hydroxyl group at solid surface of TS-1, and gives acid sites to solid itself. The existence of acid sites can enhanced hydrophilicity of TS- 1 catalyst, which can be carried out by addition of metal oxide to catalysts. Table 2 also shows the area of the peak at around $1490 \mathrm{~cm}^{-1}$ that can be assigned to total amount of acid sites (Brønsted and Lewis). The table shows that the area increases as $\mathrm{V}_{2} \mathrm{O}_{5}$ loading increases up to $4 \mathrm{wt} \%$. In this study, it is suggested that the coordinately bonding of vanadium species with hydroxyl groups on the surface of TS- 1 can be correlated with
Brønsted acid sites. According to Table 2, reported that the increasing of the acid site both Lewis and Brønsted are accompanied with the increasing of metal oxide $\mathrm{V}_{2} \mathrm{O}_{5}$ content at TS- 1 catalyst.

The specific surface area of TS- 1 and $\mathrm{V}_{2} \mathrm{O}_{5} / \mathrm{TS}-1$ catalyst samples was meansured based on the BrunauerEmmett-Teller (BET) isotherm using nitrogen adsorption. Figure 4 illustrates the $\mathrm{N}_{2}$ adsorption / desorption isotherm of TS- 1 and $\mathrm{V}_{2} \mathrm{O}_{5} /$ TS- 1 catalyst samples. The isotherm of TS- 1 and $\mathrm{V}_{2} \mathrm{O}_{5}$ / TS- 1 catalyst samples exhibits a sharp transition in adsorption branch followed by a linear section with a very gentle slope, which indicates its microporous structure. The hysteresis loop at high $P / P_{0}(0.9-1.0)$ can be attributed to the interparticle spaces formed by the nanometer sized particles. Surface area progressively decreases with increasing $\mathrm{V}_{2} \mathrm{O}_{5}$ concentration. Table 3 shows the surface area of the catalyst samples. Similar finding have been reported by $\mathrm{Li}$ et al. [21], which reported that specific surface area of TS-1 catalyst is approximately $310-463 \mathrm{~m}^{2} / \mathrm{g}$.

The results of hydrophobic tests are shown in Table 4. TS- 1 and $\mathrm{V}_{2} \mathrm{O}_{5} / \mathrm{TS}-1$ catalyst samples seem to show similar behavior during the hydrophilicity test. It indicates that the addition of metal oxide $\mathrm{V}_{2} \mathrm{O}_{5}$ on TS-1 surface doesn't give too much effect in TS-1 catalyst properties, which is partially hydrophobic. The criterion of partially hydrophobic samples is samples float on the phase interface, after mixing for a long time, some particles still float on the phase interface.

Nevertheless, the addition of metal oxide $\mathrm{V}_{2} \mathrm{O}_{5}$ on TS-1 surface resulted higher hydrophilicity of $\mathrm{V}_{2} \mathrm{O}_{5}$ /TS-1 catalysts than that of TS- 1 catalyst. Table 4 shows that the higher $\mathrm{V}_{2} \mathrm{O}_{5}$ loading in TS- 1 catalyst results in the faster sinks of $\mathrm{V}_{2} \mathrm{O}_{5} / \mathrm{TS}-1$ catalysts into water. It proved that the increasing of the catalyst hydrophilicity character is accompanied with the increasing of metal oxide $\mathrm{V}_{2} \mathrm{O}_{5}$ content at TS- 1 catalyst.

\section{B. Catalytic Activity}

The catalytic activity of the $\mathrm{V}_{2} \mathrm{O}_{5}$, TS- 1 , and $\mathrm{V}_{2} \mathrm{O}_{5} / \mathrm{TS}$ 1 catalysts were tested in the hydroxylation of benzene using $\mathrm{H}_{2} \mathrm{O}_{2}$ as oxidant and acetoneitrile as solvent at $70^{\circ} \mathrm{C}$. The main product of the reaction was phenol. Figure 6 shows the graph of the rate of formation of phenol versus reaction time in the hydroxylation of benzene using acetoneitrile as solvent.

All of samples show activity towards the the hydroxylation of benzene. Compared to $\mathrm{V}_{2} \mathrm{O}_{5} / \mathrm{TS}-1$ catalysts, sample TS- 1 shows the lowest rate of the formation of phenol. Therefore, the high rate of phenol formation observed in the reaction mixture catalyzed by samples $\mathrm{V}_{2} \mathrm{O}_{5} / \mathrm{TS}-1$ may be due to the presence of $\mathrm{V}_{2} \mathrm{O}_{5}$ in the catalysts. However, the yield of phenol decreased as $\mathrm{V}_{2} \mathrm{O}_{5}$ loading increased in all reaction time.

Because the catalysts which is used in the reaction have the similar amount of TS-1, this finding suggest that in this condition, the $\mathrm{V}_{2} \mathrm{O}_{5}$ is not active in the hydroxylation of benzene, but low concentration of $\mathrm{V}_{2} \mathrm{O}_{5}$ improves catalytic activity. Furthermore, for the activity of $\mathrm{V}_{2} \mathrm{O}_{5} / \mathrm{TS}-1$ catalysts, as can be seen in Figure 6 that the rate of phenol formation increased very rapidly at the 
initial stage, and then further increased gradually with the reaction time up to $6 \mathrm{~h}$. The high rate of the formation of phenol observed in the initial stage of reaction time on $\mathrm{V}_{2} \mathrm{O}_{5} / \mathrm{TS}-1$ catalysts can be explained in term of the hydrophilicity of the catalysts. Generally, in the catalytic reaction by heterogeneous catalysts, the first step of the reaction involve adsorption of the substrate on the surface of the catalysts to form intermediate, followed by reaction in the catalyst, and finally desorption of the product from the catalyst. In this reaction, the benzene is a non-polar molecule, while $\mathrm{H}_{2} \mathrm{O}_{2}$ a polar molecule. Therefore, benzene will be adsorbed immediately at the catalyst with high hydrophobicity. Sample TS-1 has higher hydrophobic properties than $\mathrm{V}_{2} \mathrm{O}_{5} \mathrm{TS}-1$. Consequently, when catalyst TS- 1 is added into the solution of phenol and $\mathrm{H}_{2} \mathrm{O}_{2}$, the adsorption of phenol on the TS- 1 is faster than that of $\mathrm{H}_{2} \mathrm{O}_{2}$. Meanwhile, it is known that in the benzene hydroxylation, the active sites are peroxo-titanium complex which is formed by interaction of titanium species of TS-1 with hydrogen peroxide. Therefore, it is expected that the faster interaction of $\mathrm{H}_{2} \mathrm{O}_{2}$ with titanium in the TS-1 result the faster formation of peroxo-titanium species. As a result, the formation of phenol was found to be increased. Based on these finding, it is concluded that the high rate of the formation of phenol observed on $\mathrm{V}_{2} \mathrm{O}_{5} / \mathrm{TS}-1$ catalysts may due to the higher hydrophilicity of these catalysts as compare with sample TS-1.

Figure 4 shows the dependence of the TOF (mol oxide/mol titanium/h) on the amount of $\mathrm{V}_{2} \mathrm{O}_{5}$ loading in $\mathrm{V}_{2} \mathrm{O}_{5} /$ TS-1 for the hydroxylation of benzene with aqueous $\mathrm{H}_{2} \mathrm{O}_{2}$ at $70^{\circ} \mathrm{C}$ for $6 \mathrm{~h}$. All $\mathrm{V}_{2} \mathrm{O}_{5} / \mathrm{TS}-1$ catalysts showed higher TOF than the parent TS-1. Among the $\mathrm{V}_{2} \mathrm{O}_{5} / \mathrm{TS}-1$ catalysts, it is found that the TOF decreased sharply with an increasing amount of $\mathrm{V}_{2} \mathrm{O}_{5}$ loading. This finding suggests that the capability of substrate to access the peroxo-titanium active sites inside the pore of TS- 1 is easier at lower amount of $\mathrm{V}_{2} \mathrm{O}_{5}$ loading. The pore opening of TS-1 is blocked by vanadium oxide at the high amount of $\mathrm{V}_{2} \mathrm{O}_{5}$ loading. Meanwhile, the higher activity observed in the sample with lower $\mathrm{V}_{2} \mathrm{O}_{5}$ loading indicated that only small amount of $\mathrm{V}_{2} \mathrm{O}_{5}$ is needed to increase the hydrophilicity of TS-1 to form peroxotitanium species. Similar findings have been reported by Prasetyoko et al. [11], which reported that the yield of 1,2-epoxyoctane from 1-octene epoxidation decreased as $\mathrm{WO}_{3}$ loading in TS- 1 increased higher that $7 \mathrm{wt} \%$ due to the blocking pores of TS-1 by tungsten oxide $\mathrm{WO}_{3}$ at the high amount of $\mathrm{WO}_{3}$ loading in TS-1.

\section{CONCLUSION}

Impregnation of vanadium oxides $\left(\mathrm{V}_{2} \mathrm{O}_{5}\right)$ onto titanium silicalite (TS-1) was studied. The XRD data showed that after incorporation of vanadium oxides, the MFI structure of TS-1 still remained. Bronsted acid sites have been generated in the $\mathrm{V}_{2} \mathrm{O}_{5} / \mathrm{TS}-1$ catalysts. It was suggested that the Brønsted acid sites were formed due to formation of $\mathrm{Si}-\mathrm{O}-\mathrm{V}$ bond in the $\mathrm{V}_{2} \mathrm{O}_{5} / \mathrm{TS}-1$ catalysts. The increasing of the acid sites both Lewis and Bronsted acids are accompanied with the increasing of metal oxide $\mathrm{V}_{2} \mathrm{O}_{5}$ content at TS-1 catalyst. Catalyst hydrophilicity character increases successively from TS-1, 0,5 $\mathrm{V}_{2} \mathrm{O}_{5} /$ TS- $1,1 \mathrm{~V}_{2} \mathrm{O}_{5} / \mathrm{TS}-1,2 \mathrm{~V}_{2} \mathrm{O}_{5} / \mathrm{TS}-1$, and $4 \mathrm{~V}_{2} \mathrm{O}_{5} / \mathrm{TS}-1$. In the hydroxylation of benzene with aqueous $\mathrm{H}_{2} \mathrm{O}_{2}$ in acetoneitrile as a solvent, the $\mathrm{V}_{2} \mathrm{O}_{5} / \mathrm{TS}-1$ catalysts showed higher activity than the unloaded TS-1 due to higher hydrophylicity of the $\mathrm{V}_{2} \mathrm{O}_{5}$ / TS-1 catalysts.

\section{ACKNOWLEDGEMENT}

We gratefully acknowledge funding from the Directorate General of Higher Education, Indonesia, under Hibah Kompetensi and The Academy of Sciences for the Developing World (TWAS) Research Grant.

\section{REFERENCES}

[1] G. Tanarungsun, W. Kiatkittipong, P. Praserthdam, H. Yamada, T. Tagawa, and S. Assabumrungrat, "Hydroxylation of benzene to phenol on $\mathrm{Fe} / \mathrm{TiO}_{2}$ catalysts loaded with different types of second metal", Catalysis Communications, Vol. 9, pp. 1886-1890, 2008.

[2] M. H. Sayyar, and R. J. Wakeman, "Comparing Two New Routes for. Benzene Hydroxylation", Chemical engineering research and design, Vol. 86, pp. 517-526, 2008.

[3] J. Chen, S. Gao, and J. Xu, "Direct hydroxylation of benzena to phenol over a new vanadium-substituted phosphomolybdate as a solid catalyst", Catalysis communications, Vol. 9, pp. 728-733, 2008.

[4] X. Gao and J. Xu, "A new application of clay-supported vanadium oxide catalyst to selective hydroxylation of benzena to phenol", Applied clay science, Vol. 33, pp. 1-6, 2006.

[5] X. Liu, X. Wang, X. Guo, and G. Li, "Effect of solvent on the propylene epoxidation over TS-1 catalyst", Catalysis today, Vols. 93-95, pp. 505-509, 2004.

[6] A. Bhaumik, P. Mukherjee, and R. Kumar, "Triphase catalysis over titanium-silicate molecular sieves under solvent-free conditions", Journal of Catalysis, Vol. 178, pp. 101-107, 1998.

[7] F. Bonino, A. Damin, G. Ricchiardi, M. Ricci, G. Spano', D'Aloisio, R. A. Zecchina, C. Lamberti, C. Prestipino, and S. Bordiga, "Ti-peroxo species in the TS-1/ $\mathrm{H}_{2} \mathrm{O}_{2} / \mathrm{H}_{2} \mathrm{O}$ system", Journal of Physical Chemistry B, Vol. 108, pp. 3573-3583, 2004.

[8] Y. Liu, X. Ma, S. Wang, and J. Gong, "The nature of surface acidity and reactivity of $\mathrm{MoO}_{3} / \mathrm{SiO}_{2}$ and $\mathrm{MoO}_{3} / \mathrm{TiO}_{2}-\mathrm{SiO}_{2}$ for transesterification of dimethyl oxalate with phenol", Applied catalysis B: environmental, Vol. 77, pp. 125-134, 2007.

[9] G. N. Vayssilov and R.A. Van Santen, "Catalytic activity of titanium silicates - a DFT study", Journal of Catalysis, Vol. 175, pp. 170-174, 1998.

[10] H. Nur, D. Prasetyoko, Z. Ramli, and S. Endud, "Sulfation: a simple methode to enhance the catalytic activity of TS-1 in epoxidation of 1-octene with aqueous hydogen peroxide", Catalysis communications, Vol. 5, pp. 725-728, 2004.

[11] D. Prasetyoko, Z. Ramli, S. Endud, and H. Nur, "Enhancement of catalytic activity of titanosilicalite-1-sulfated zirconia combination towards epoxidation of 1-octene with aqueous hydrogen peroxide", Reaction kinetics catalysis letter, Vol. 86, pp. 83-89, 2005.

[12] S. Indrayani, "Aktivitas katalitik $\mathrm{MoO}_{3} / \mathrm{TS}-1$ pada reaksi hidroksilasi fenol menggunakan $\mathrm{H}_{2} \mathrm{O}_{2}$ ", Thesis $M$. Si, Institut Teknologi Sepuluh Nopember, 2008.

[13] M. Taramasso, G. Perego, and B. Notari, "Preparation of porou crystalline synthetic material comprised of silicon and titanium oxides", US Patents 4,410,501, 1983.

[14] S. Shylesh, T. Radhika, S. K. Rani, and S. Sugunan, "Synthesis, characterization and catalytic activity of $\mathrm{Nd}_{2} \mathrm{O}_{3}$ supported $\mathrm{V}_{2} \mathrm{O}_{5}$ catalysts", Journal of Molecular Catalysis A: Chemical, Vol. 236, pp. 253-259, 2005

[15] Z. Wang, T. Wang, Z. Wang, and Y. Jin,"Organic modification of ultrafine particles using carbon-dioxide as the solvent", Journal of Powder Technolog, Vol. 139, pp. 148-155, 2004.

[16] Y.G. Li, Y.M. Lee, and J.F. Porter, "The Synthesis and Caracterization of. Titanium Silicalite-1", Kluwer Academic Publishers, pp. 0022-2461, 2002.

[17] K.V. R. Chary, G. Kishan, C. P. Kumara, G. V. Sagar, and J.W. Niemantsverdriet, "Characterization and reactivity of vanadium oxide catalysts supported on niobia”, Applied catalysis A: general, Vol. 245, pp. 303-316, 2003. 
[18] Q. Sun, D. Fang, S. Wang, J. Shen, and A. Auroux, Applied catalysis A, Vol. 327, pp. 218-225, 2007.

[19] R.S. Drago, S.C. Dias, J.M. McGilvray, and A.L.M.L. Mateus, "Acidity and hydrophobicity of TS-1", Journal of Physical Chemistry, Vol. 102, pp. 1508-1514, 1998.

[20] G. Li, X. Wang, X. Guo, S. Liu, Q. Zhao, X. Bao, and L. Lin, "Titanium species in titanium silicate TS-1 prepared by hydrothermal method", Materials chemistry and physics, Vol. 71, pp. 195-201, 2001.

[21] C.A. Emeis, "Determination of integrated molar extinction coefficients for infrared absorption of pyridine adsorbed on solid acid catalysts", Journal of Catalysis, Vol. 141, pp. 347-354, 1993.

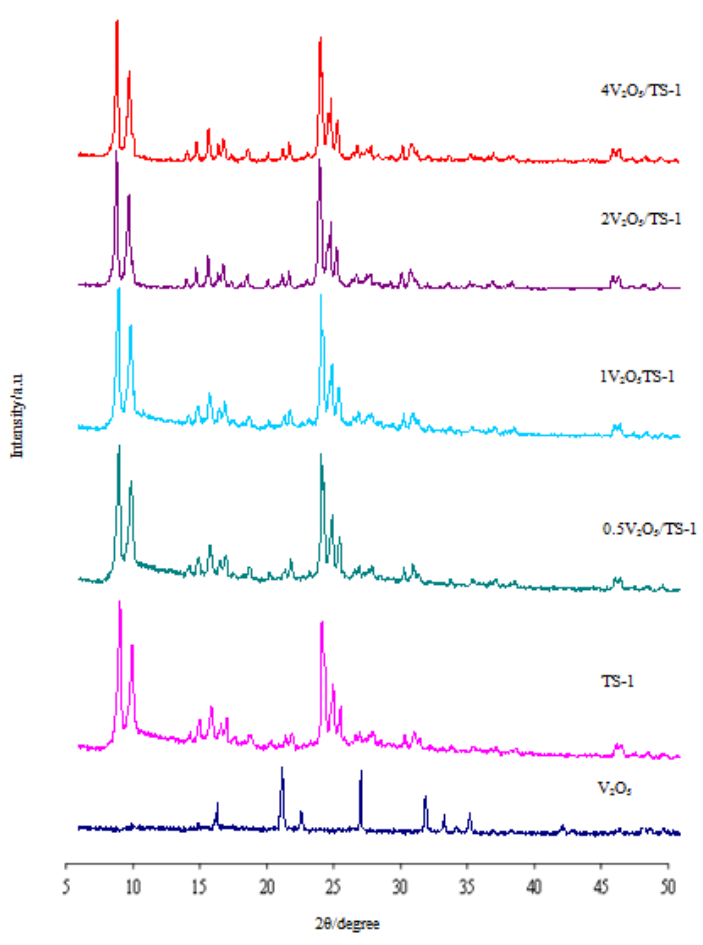

Figure 1. X-ray diffraction pattern of the $\mathrm{V}_{2} \mathrm{O}_{5}$, TS-1, and $X \mathrm{~V}_{2} \mathrm{O}_{5} / \mathrm{TS}-1(X=0.5,1-2$, and 4) catalyst samples

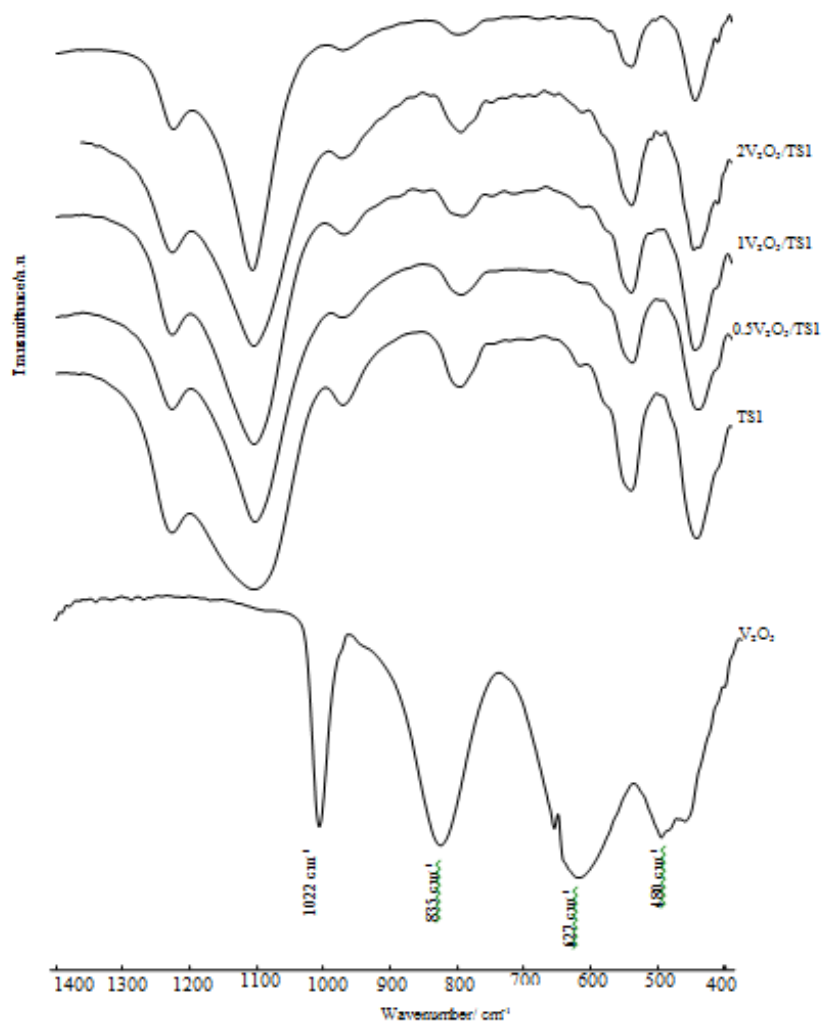

Figure 2. FTIR spectra of the $\mathrm{V}_{2} \mathrm{O}_{5}$, TS-1, and $X \mathrm{~V}_{2} \mathrm{O}_{5} / \mathrm{TS}-1(X=0.5,1-2$, and 4) catalyst samples 


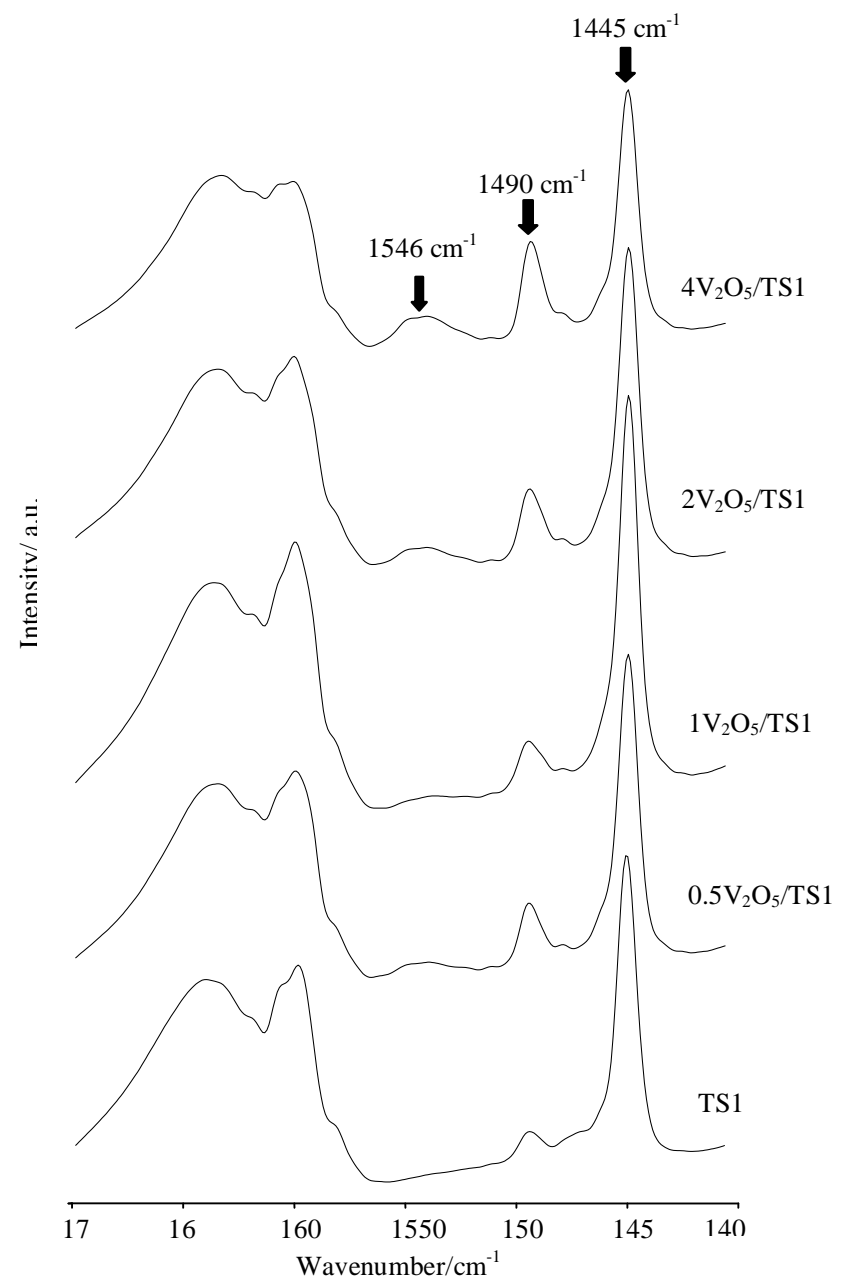

Figure 3. Infrared spectra of the TS- 1 and $X \mathrm{~V}_{2} \mathrm{O}_{5} / \mathrm{TS}-1\left(X=0.5,1-2\right.$, and 4) catalyst samples after evacuation at $400^{\circ} \mathrm{C}$ in the nitrogen flow, followed by pyridine adsorption at room temperature and desorption at $150^{\circ} \mathrm{C}$ for $3 \mathrm{~h}$

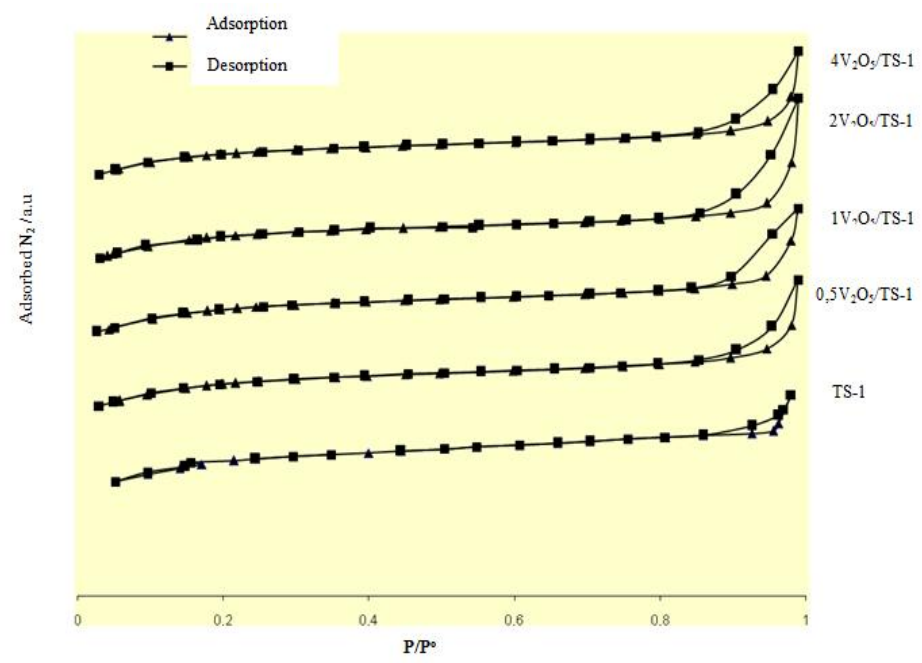

Figure 4. $\mathrm{N}_{2}$ adsorption-desorption isotherms of the calcined TS-1 and $X \mathrm{~V}_{2} \mathrm{O}_{5} / \mathrm{TS}-1(X=0.5,1-2$, and 4) catalyst samples 


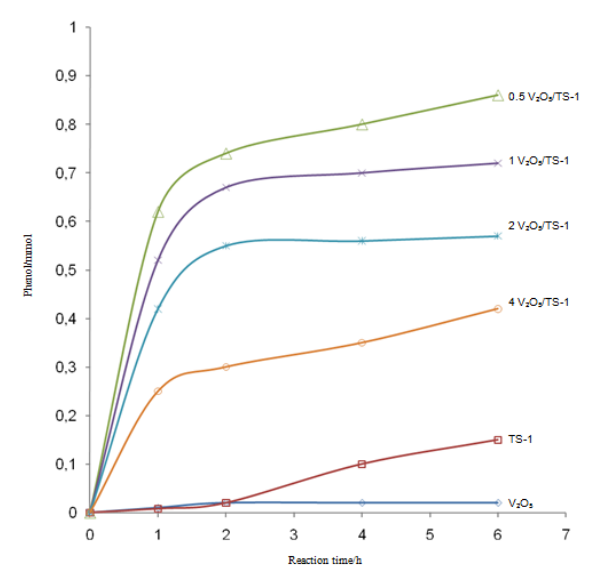

Figure 5. The formation of phenol from benzene hydroxylation using aqueous $\mathrm{H}_{2} \mathrm{O}_{2}$ at $70^{\circ} \mathrm{C}$ catalyzed by TS- 1 and $\mathrm{V}_{2} \mathrm{O}_{5}$ / TS-1

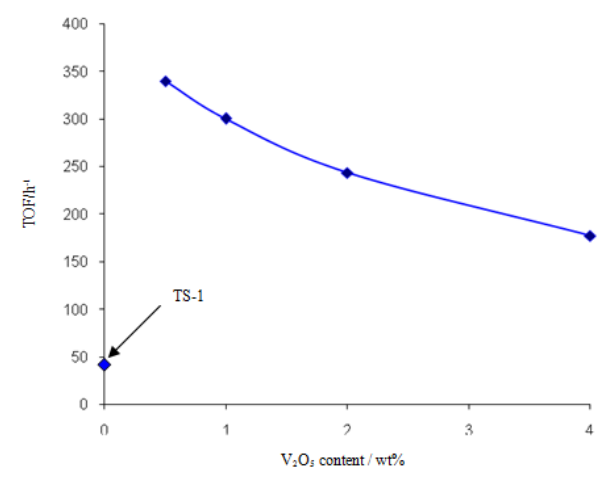

Figure 6. Dependence of TOF (mol phenol per mol Ti, per hour at $6 \mathrm{hrs}$ of reaction time) on the $\mathrm{V}_{2} \mathrm{O}_{5}$ content for hydroxylation benzene with aqueous hydrogen peroxide at $70^{\circ} \mathrm{C}$ in acetoneitrile

TABLE 1.

CRYstallinity OF THE TS-1 AND $X \mathrm{~V}_{2} \mathrm{O}_{5} / \mathrm{TS}-1$ ( $X=0.5,1-2$, AND 4) CATALYST SAMPles

\begin{tabular}{cccc}
\hline Samples & $\begin{array}{c}\text { Intensity at around } \\
2 \theta=23.00^{\circ}, \mathrm{Cps}\end{array}$ & $\begin{array}{c}\text { Relative Crystallinity } \\
(\%)\end{array}$ & phase \\
\hline TS-1 & 2871 & 100 & MFI \\
$0.5 \mathrm{~V}_{2} \mathrm{O}_{5} /$ TS- 1 & 2852 & 99.34 & MFI \\
$1 \mathrm{~V}_{2} \mathrm{O}_{5} /$ TS- 1 & 2786 & 97.04 & MFI \\
$2 \mathrm{~V}_{2} \mathrm{O}_{5} /$ TS- 1 & 2504 & 87.22 & MFI \\
$4 \mathrm{~V}_{2} \mathrm{O}_{5} /$ TS- 1 & 2366 & 82.41 & MFI \\
\hline
\end{tabular}

TABLE 2.

AMOUNT OF LEWIS AND BRøNSTED ACID SITES (MMOL/G) OF THE TS-1 AND $X \mathrm{~V}_{2} \mathrm{O}_{5} / \mathrm{TS}-1$ ( $X=0.5,1-2$, AND 4) CATALYST SAMPLES

\begin{tabular}{|c|c|c|c|c|}
\hline \multirow{2}{*}{ Samples } & \multicolumn{2}{|c|}{ Acid site, $\mathrm{mmol} / \mathrm{g}$} & \multirow{2}{*}{ Ratio B/L } & \multirow{2}{*}{$\begin{array}{l}\text { Peak Area a } \\
1490, \mathrm{~cm}^{-1}\end{array}$} \\
\hline & Bronsted (B) & Lewis (L) & & \\
\hline TS-1 & - & 0.965 & 0 & 4.612 \\
\hline $0,5 \mathrm{~V}_{2} \mathrm{O}_{5} / \mathrm{TS}-1$ & 0.319 & 1.453 & 0.220 & 6.350 \\
\hline $1 \mathrm{~V}_{2} \mathrm{O}_{5} / \mathrm{TS}-1$ & 0.619 & 1.581 & 0.392 & 6.554 \\
\hline $2 \mathrm{~V}_{2} \mathrm{O}_{5} / \mathrm{TS}-1$ & 0.901 & 1.239 & 0.727 & 7.815 \\
\hline $4 \mathrm{~V}_{2} \mathrm{O}_{5} / \mathrm{TS}-1$ & 1.061 & 0.974 & 1.089 & 9.159 \\
\hline
\end{tabular}

TABLE 3 .

Average Surface AREA OF THE TS-1 AND $X \mathrm{~V}_{2} \mathrm{O}_{5} / \mathrm{TS}-1(X=0.5,1-2$, AND 4$)$ CATAlyst SAMPLES

\begin{tabular}{cc} 
Samples & BET Surface Area $\left(\mathrm{m}^{2} / \mathrm{g}\right)$ \\
\hline TS-1 & 394.88 \\
$0,5 \mathrm{~V}_{2} \mathrm{O}_{5} /$ TS- 1 & 393.81 \\
$1 \mathrm{~V}_{2} \mathrm{O}_{5} /$ TS- 1 & 391.27 \\
$2 \mathrm{~V}_{2} \mathrm{O}_{5} /$ TS-1 & 387.32 \\
$4 \mathrm{~V}_{2} \mathrm{O}_{5} /$ TS-1 & 348.13 \\
\hline
\end{tabular}

TABLE 4.

HYDROPHOBICITY CHARACTER OF THE TS-1 AND $X \mathrm{~V}_{2} \mathrm{O}_{5} / \mathrm{TS}-1$ ( $X=0.5,1-2$, AND 4$)$ CATALYST SAMPLES

\begin{tabular}{cccc}
\hline Samples & Index & Character & Time to sink into the water (s) \\
\hline TS-1 & 5 & Hydrophobic Partial & 72 \\
$0,5 \mathrm{~V}_{2} \mathrm{O}_{5} /$ TS- 1 & 5 & Hydrophobic Partial & 63 \\
$1 \mathrm{~V}_{2} \mathrm{O}_{5} /$ TS- 1 & 5 & Hydrophobic Partial & 54 \\
$2 \mathrm{~V}_{2} \mathrm{O}_{5} /$ TS- -1 & 5 & Hydrophobic Partial & 35 \\
$4 \mathrm{~V}_{2} \mathrm{O}_{5} /$ TS- -1 & 5 & Hydrophobic Partial & 24 \\
\hline
\end{tabular}

